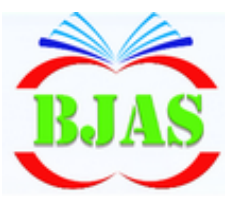

ISSN $1814-5868$
Available online at http://bajas.edu.iq https://doi.org/10.37077/25200860.2019.208 College of Agriculture, University of Basrah

Basrah J. Agric. Sci., 32(2): 176-192, 2019

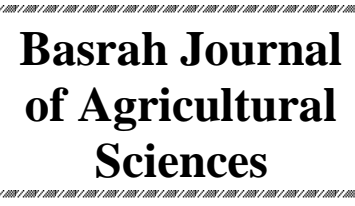

E-ISSN: 2520-0860

\title{
Effect of Dietary Prebiotic Safmannan and Bio-antibiotic Fluconazole on some Growth and Haemato-immunological Parameters of Common Carp Cyprinus carpio Linnaeus
}

\author{
Safa M. Imran, Atheer H. Ali \& Salah M. Najim \\ Department of Fisheries and Marine Resources, College of Agriculture, University of \\ Basrah, Iraq \\ *Corresponding author E-mail:safaalshmre@yahoo.com \\ Received 19 September 2019; Accepted 18 November 2019; Available online 31 December 2019
}

\begin{abstract}
This study was conducted in the laboratories of the College of Agriculture, University of Basrah for 75 days, in order to study the effect of using prebiotic (Safmannan) and bio-antibiotic (Fluconazole) on some growth and haemato-immunological parameters of the common carp Cyprinus carpio L. The fishes were divided into four categories of treatments; the first treatment was the control (basal diet), the second and third treatments (T2 and T3) contained 500 and $1000 \mathrm{mg} \cdot \mathrm{kg}^{-1}$ diet of Safmannan, respectively while the fourth treatment consisted of adding $150 \mathrm{mg} .100 \mathrm{~g}^{-1}$ diet of bio-antibiotic Fluconazole. The second and third treatments were significantly higher $(\mathrm{P}<0.05)$ than control and antibiotic treatments in the growth parameters such as the average of daily weight gain, the average of specific growth and the feed conversion of the second and third treatments. Blood proteins (albumin, globulin and total protein) showed significantly higher $(\mathrm{p}<0.05)$ values in the second and third treatments than control and antibiotic treatments. No significant differences were noted in both packed cells volume (PCV) and haemoglobin ( $\mathrm{Hb}$ ) among different treatments. The value of alanine aminotransferase (ALT) showed no significant differences among all treatments, while alkaline phosphatase (ALP) was significantly higher and aspartate transaminase (AST) was significantly lower in the fourth treatment. Hepatosomatic index (HSI) was significantly higher in all treatments compared with the control, while no significant differences in spleen somatic index (SSI) were noted among all treatments. Differential white blood count exhibited no significant differences among the treatments for eosinophils, basophils, lymphocytes and monocytes, while neutrophil count was significantly decreased in all treatments in comparison with the control.
\end{abstract}

Keywords: Fish, Dietary supplement, Safmannan, Fluconazole, Health, Haematology.

\section{Introduction}

Fish resources are considered as one of the main pillars for the productive base in livestock, so the importance of fish aquaculture has grown over the past years due to the great advantages enjoyed by this activity. Common carp (Cyprinus carpio L.) remains the most important group among aquatic organisms,

which contributes to $72 \%$ of the freshwater production, because it has the ability to withstand the environmental conditions of 


\section{Imran et al / Basrah J. Agric. Sci., 32 (2):186-202, 2019}

temperature and oxygen concentration reduction bellow $4.5 \mathrm{mg} . \mathrm{I}^{-1}$ (Baldry, 2000; Kühlwein et al., 2014). The expanding of aquaculture, the spread of intensive and semiintensive culture, and the competition to get higher production in growth averages have led to problems that have accompanied these activities, e.g. the emergence of diseases, often due to increased production, in the limited unit area (Chen et al., 2014). The use of antibiotics and chemotherapy to overcome these problems and diseases have led to the spread of drugresistant strains of bacteria and fungi and the weakening of the immune system of fishes (Brogden et al., 2014; Allameh et al., 2016).

The accumulation of antibiotics in both the environment and fishes possess a potential risk to consumers and the environment (Carrias et $a l .$, 2012). Furthermore, due to the various fungal infections, drugs and medicines were used in treating these infections, but there was a significant evolution in resistance of the fungi to antibiotics and the failure of some of these antibiotics in treating most disease cases (Wisplinghof et al., 2014). As a result, many researchers have recently turned their attention to the use of dietary supplements in addition to remedies and vaccines, where an alternative method was found to enhance the resistance of pathogens, immune responses and other health benefits, namely the addition of probiotic and prebiotic, which have a variety of traits to enhance the health that improve fish immunity and increase the nutritional value of the diet. It stimulates growth, immune system development, improves feed digestion as well as other health and productivity benefits (Tuan, 2013; Bandyopadhyay et al., 2015). This study aims to test the effect of adding prebiotic (Safmannan) and bio-antibiotic (Fluconazole), in fish diets, on some growth and heamatoimunological criteria of the common carp.

\section{Materials \& Methods}

\section{Fishes of the experiment and water quality}

A total of 130 common carp fries (10.8-11.5 g in weight) were used. The fishes were sterilized with a saturated salt solution $(\mathrm{NaCl})$ for approximately 35-40 seconds (Herwig, 1979) to get rid of any external disease agents. The fishes were randomly distributed into 13 glass aquariums, acclimatized for 14 days in preprepared glass aquariums for research measures $(30 \times 40 \times 60 \mathrm{~cm})$, and filled by 50 -litres of aged tap water. The fishes were fed the control diet during the period of acclimatization, which was manufactured in the laboratory (table 1). The temperature was measured by a mercury thermometer with a gradient of $0-100{ }^{\circ} \mathrm{C}$. The dissolved oxygen concentration was measured by using the modified Winkler's method and $\mathrm{pH}$ by using $\mathrm{pH}-009-1-\mathrm{A}$ Meter while a WTW electrical conductivity device was used to measure water salinity.

\section{Fish-diet formulation}

Table (1) explained the percentages of different diet ingredients used in control diet. Each of feed item was grinded alone by laboratory mill (Hinduston-MFG-Co, England) and after mixing all of the ingredients for homogeneity, the diet put in Rapid Content Analyser to determine the chemical composition of the diet as shown in table (2). The contents of French commercial prebiotic (Safmannan) was shown in table (3). Antifungal fluconazole (=Forcan150 , Indian origin) was added to the control diet to form the fourth treatment (T4). Four experimental treatments were formed including 


\section{Imran et al / Basrah J. Agric. Sci., 32 (2):186-202, 2019}

basal (control) treatment. The control (T1) with two replicates, antibiotic with three and the rest (T2 and T3 of safmannan) with four replicates each. In each replicate, ten fishes were used. The homogeneity of the components for each diet was taken into account when the diet was prepared (Lovell, 1989). Hot water was gradually added up to $600 \mathrm{ml} . \mathrm{kg} \operatorname{diet}^{-1}$, then manually mixed and the mixture temperature was raised to $75^{\circ} \mathrm{C}$. The mixture was then left to cool down and then the additives from the fluconazole or safmannan were added and then mixed well with ingredients until the formation of a dried paste, which was entered into a $50 \mathrm{ml}$ plastic syringe to form yarns with a size of 5 $\mathrm{mm}$. The yarns of the four treatments were spread in the laboratory and exposed to air with constant flux until dry.

Table (1): The proportions of the calculated diet components as a dry matter.

\begin{tabular}{cc}
\hline Diet item & Percentage \\
\hline Flour & 25 \\
\hline Soybean meal & 25 \\
\hline Fish meal & 25 \\
\hline Yellow corn & 10 \\
\hline Black barley & 10 \\
\hline Fine flour bran & 5 \\
\hline Total & 100
\end{tabular}

Table (2): Chemical contents of the basal diet by Rapid Content Analyser.

\begin{tabular}{cc}
\hline Component & Percentage \\
\hline Humidity & 7.95 \\
\hline Crud protein & 31.67 \\
\hline Ether extract & 3.09 \\
\hline Ash & 7.60 \\
\hline Crud fibre & 1.64 \\
\hline Nitrogen free extract (NFE) & 48.05 \\
\hline
\end{tabular}

Table (3): The composition of prebiotic Safmannan.

\begin{tabular}{cc}
\hline Component & Percentage \\
\hline Humidity & 6 \\
\hline Crud protein & 17.5 \\
\hline Ether extract & 20 \\
\hline B-Glucan & 20 \\
\hline Mannan oligosaccharide & 20
\end{tabular}




\section{Imran et al / Basrah J. Agric. Sci., 32 (2):186-202, 2019}

Each diet was placed after drying in a labelled nylon bag and kept in refrigerator at a temperature of $-4{ }^{\circ} \mathrm{C}$ until use. The fishes were starved for two days and then fed on the control diet by $3 \%$ of diet per body weight for two weeks. The experiment lasted for 75 days exclusive of the acclimation period (14 days). Water was ventilated throughout the experiment by using air pumps, and $20-25 \%$ of the water of aquarium were exchanged daily with new amount that was left in a stock tank for a period of 24 hours. Clips wire was used to cover the aquarium to prevent fishes from escaping outside. After finishing the acclimation period, fishes were fed experimental diet two time a day at 8 am and 2 pm. Feeding was adjusted after measuring the weight of the fishes every 15 days to monitor growth using a Metler PE600 sensitive balance.

\section{Growth parameters}

Specific Growth Rate (S.G.R), Feed Conversion Ratio (FCR) and Daily Weight Gain (DWG) were calculated according to Hepher (1988).

\section{Haemato-immunological analyses}

Fishes were fasted for 24 hours prior to blood sampling. The blood was withdrawn from different groups of fishes after cutting the caudal peduncle. Each fishes was caught in a way where the head was to the top which helped to flow the blood by fine massage on the caudal peduncle and filled the capillary tubes which contained the anticoagulant, where one of the ends was closed with artificial clay (Plastine), then the capillary tubes were placed in the microhaematocrit centrifuge to separate the serum from the plasma at $3000 \mathrm{rpm}$ for two minutes (Yang \& Chen, 2003). The serum was then kept in glass tube and placed in a freezer until the laboratory tests, where it was measured.

\section{Packed cell volume (PCV)}

It was read by a microhaematocrit reader and represents the packed cell volume per $100 \mathrm{ml}$ of blood.

\section{Haemoglobin (Hb)}

Haemoglobin was directly calculated by the packed cell volume, using the equation mentioned by Campbell (1995) which is:

$$
\text { Haemoglobin }(\mathrm{Hb})=\frac{\text { Packed cell volume }-1}{3}
$$

\section{Blood proteins}

Serum albumin, total protein and cholesterol were calculated by using special kit from German company "Human" and measured at a wavelength of $570 \mathrm{~nm}, 580 \mathrm{~nm}$ and $500 \mathrm{~nm}$, respectively by using the Polish spectrophotometer "Philips"(model SP-3000 plus) according to the attached method of work by the concerned company.

The level of globulin in serum was estimated according to Wolf \& Darlington (1971) through the following equation 


\section{Globulin $\left(\mathrm{mg} .100 \mathrm{ml}^{-1}\right.$ serum $)=$ Total protein- Albumin .}

Albumin/globulin ratio (A/G) was estimated by dividing the albumin to globulin (Richards \& Pickering, 1979).

\section{Liver enzymes}

The concentration of alanine aminotransferase (ALT), aspartate transaminase (AST) and alkaline phosphatase (ALP) enzymes in the serum were estimated by using special kit from a German company (Human) and read at a wavelength of $400 \mathrm{~nm}, 340 \mathrm{~nm}$ and $550 \mathrm{~nm}$, respectively against distilled water by using Polish spectrophotometer "Philips"(model SP3000 plus) according to the attached method attached by the company.

\section{Differential white blood cell count}

A thin blood film was prepared, fixed in methyl alcohol solution and then stained with Giemsa stain. White blood cells were calculated on a $400 x$ as a general view of the slide, then the cells were differentiated by 1000x. Randomly count 100 of different types of WBCs e.g. monocytes, lymphocyte, neutrophil, eosinophils and basophils and identified according to Mumford et al. (2007) and Palić et al. (2011).

\section{Some biological measurements}

Samples of fishes were randomly taken from all treatment groups and the internal organs were carefully isolated. The liver and spleen were weighed by using a Chinese sensitive balance (type XY-8006) and the following equations were applied to determine the hepatosomatic index (HSI) and spleen somatic index (SSI) according to Schreck \& Moyle (1990).

$$
\begin{aligned}
& \text { HSI } \%=\frac{\text { Liver weight }(\mathrm{g})}{\text { weight of fish }} \times 100 . \\
& \text { SSI } \%=\frac{\text { Spleen weight }(\mathrm{g})}{\text { Fish weight }} \times 100
\end{aligned}
$$

\section{Statistical analysis}

The statistical analysis system (SAS, 2012) was used in the analysis of data to study the effect of different treatments in the studied traits according to the completely randomized design (CRD). The significant differences among the means were compared with Duncan's multiple range test (Duncan, 1955).

\section{Results}

\section{Water quality}

The temperature of water in the aquariums ranged between $26-27^{\circ} \mathrm{C}$, the dissolved oxygen concentrations 6-7 mg. $\mathrm{l}^{-1}$, the $\mathrm{pH} \mathrm{8-8.4} \mathrm{and} \mathrm{the}$ salinity between 2.8 - 3.9 PSU.

\section{Growth parameters}

No mortality of fishes happened during the experiment. The daily weight gain (DWG) 


\section{Imran et al / Basrah J. Agric. Sci., 32 (2):186-202, 2019}

exhibited a significantly higher $(\mathrm{P}<0.05)$ values for the second $(500 \mathrm{mg}$ safmannan.kg $\left.\operatorname{diet}^{-1}\right)$ and third treatments (1000 mg safmannan.kg diet ${ }^{-1}$ ) which were 1.44 and 1.49 g fish.day ${ }^{-1}$, respectively compared with 0.935 and 1.06 g.fish.day ${ }^{-1}$ for control and fourth treatments (Fluconazole), respectively. Feed conversion ratio (FCR) was significantly excelled $(\mathrm{P}<0.05)$ for the second and third treatments which amounted 2.72 and 2.56, respectively compared with the first and fourth treatments which amounted 3.89 and 3.34, respectively. The averages values of the SGR\% harmony with the average values of the daily weight gain, where the values of the second and third treatments were significantly higher with 0.377 g.day $^{-1}$ and 0.422 g.day $^{-1}$, respectively in comparison with 0.270 and $0.303 \%$ g.day ${ }^{-1}$, for first and fourth treatments (Table 4).

\section{Haemato-immunological analyses}

Table (5) explained the results of blood proteins, serum cholesterol and liver enzymes. The albumin was significantly different ( $\mathrm{P}$ $<0.01)$ among the treatments. The second and third treatments recorded significant lower (2.15 and $2.23 \mathrm{mg} .100 \mathrm{ml}^{-1}$ ) compared with control and fourth treatments (2.88 and 2.63 $\mathrm{mg} .100 \mathrm{ml}^{-1}$, respectively). In the case of total protein, the third treatment was significantly ( $\mathrm{p}$ $<0.01$ ) excelled with $5.47 \mathrm{mg} .100 \mathrm{ml}^{-1}$ compared with $4.78,4.96$ and $4.84 \mathrm{mg} 100 \mathrm{ml}^{-}$ ${ }^{1}$, for the first, second and fourth treatments, respectively.

Table (4): Effect of dietary Safmannan or Fluconazole on the averages of the daily weight gain, feed conversion ratio and the Daily growth rate for common carp (Mean $\pm \mathrm{SE}$ ).

\begin{tabular}{|c|c|c|c|c|c|}
\hline Treatment & $\begin{array}{l}\text { Initial weight } \\
(\mathrm{g})\end{array}$ & $\begin{array}{c}\text { Final weight } \\
(\mathrm{g})\end{array}$ & $\begin{array}{l}\text { Daily weight } \\
\text { gain }\left(\text { g.day }{ }^{-1}\right)\end{array}$ & $\begin{array}{c}\text { Feed } \\
\text { conversion } \\
\text { ratio } \\
\end{array}$ & $\begin{array}{c}\text { Daily } \\
\text { growth rate } \\
\left.(\% \text { g.day })^{-1}\right)\end{array}$ \\
\hline \multirow{2}{*}{ Control } & $115.80 \pm$ & \pm 186.25 & $0.93 \pm$ & \pm 3.89 & \pm 0.270 \\
\hline & $5.93 \mathrm{a}$ & $10.69 \mathrm{~b}$ & $0.03 \mathrm{~b}$ & $0.21 \mathrm{a}$ & $0.01 \mathrm{~b}$ \\
\hline Safmannan & $115.30 \pm$ & \pm 223.31 & \pm 1.44 & \pm 2.72 & \pm 0.377 \\
\hline $500 \mathrm{mg} \cdot \mathrm{kg}$ diet $^{-1}$ & $7.47 \mathrm{a}$ & $10.96 \mathrm{a}$ & $0.08 \mathrm{a}$ & $0.12 \mathrm{~b}$ & $0.02 \mathrm{a}$ \\
\hline Safmannan & \pm 108.55 & & \pm 1.49 & \pm 2.56 & \\
\hline $1000 \mathrm{mg} . \mathrm{kg} \mathrm{diet} \mathrm{t}^{-1}$ & $5.62 \mathrm{a}$ & $10.96 \mathrm{a}$ & $0.15 \mathrm{a}$ & $0.18 \mathrm{~b}$ & $0.02 \mathrm{a}$ \\
\hline Fluconazole & $114.90 \pm$ & \pm 195.40 & \pm 1.06 & \pm 3.43 & $0.303 \pm$ \\
\hline $150 \mathrm{mg} .100 \mathrm{~g} \mathrm{diet}^{-1}$ & $5.7 \mathrm{a}$ & $12.9 \mathrm{~b}$ & $0.06 \mathrm{~b}$ & $0.22 \mathrm{a}$ & $0.01 \mathrm{~b}$ \\
\hline Significant level & NS & $*$ & $*$ & $* *$ & $* *$ \\
\hline
\end{tabular}

As for the globulin, it was observed a significant excelling $(\mathrm{P}<0.01)$ for the second and third treatments $\left(2.80\right.$ and $3.24 \mathrm{mg} 100 \mathrm{ml}^{-}$ ${ }^{1}$ ) compared with 1.90 and $2.21 \mathrm{mg} .100 \mathrm{ml}^{-1}$ for first and fourth treatments, respectively. The results of albumin/globulin ratio showed that the second and third treatments were signific- antly ( $\mathrm{P}<0.01)$ lower $(0.775$ and 0.719 , respectively), compared to the control and fourth treatments (1.63 and 1.72, respectively). Serum cholesterol showed a significant decrease $(\mathrm{P}<0.01)$ in the second treatment (173.81 mg.100 ml-1) followed by the third treatment $\left(184.43 \mathrm{mg} .100 \mathrm{ml}^{-1}\right)$, while the first 


\section{Imran et al / Basrah J. Agric. Sci., 32 (2):186-202, 2019}

treatment (control) and the fourth treatment recorded the highest concentration for cholesterol (204.08 and $201.70 \mathrm{mg} .100 \mathrm{ml}^{-1}$, respectively) as shown in table (5). The results showed that there was no significant difference among all treatments in the concentration of the Alanine transaminase (ALT) enzyme (1.20, 1.23, 1.19 and $1.25 \mathrm{IU}^{-1}{ }^{-1}$, respectively).
Significant $(\mathrm{P}<0.05)$ higher value was observed for the fourth treatment (54.30 $\mathrm{IU}^{-1}{ }^{-1}$ ) in Alkaline phosphatase (ALP) and significant decrease $(\mathrm{P}<0.01)$ Aspartate transaminase

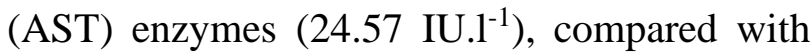
other treatments $\left(30.85,29.30\right.$ and 30.34 IU. $^{-1}$, respectively).

Table (5): Effect of dietary Safmannan or Fluconazole on the concentration of blood proteins, serum cholesterol and liver enzymes of common carp (Mean $\pm \mathrm{SE}$ ).

\begin{tabular}{|c|c|c|c|c|c|c|c|c|}
\hline Treatment & $\begin{array}{c}\text { Albumin } \\
(\mathrm{mg} .100 \\
\left.\mathrm{ml}^{-1}\right)\end{array}$ & $\begin{array}{c}\text { Total } \\
\text { protein } \\
\left(\mathrm{mg}^{2} 100 \mathrm{ml}^{-1}\right)\end{array}$ & $\begin{array}{c}\text { Globulin } \\
\left(\mathrm{mg} .100^{-}\right. \\
\left.{ }^{1} \mathrm{ml}\right)\end{array}$ & $\mathrm{A} / \mathrm{G}$ & $\begin{array}{l}\text { Cholesterol } \\
\left(\mathrm{mg} \cdot 100^{-1}\right. \\
\mathrm{ml})\end{array}$ & $\begin{array}{l}\text { ALT } \\
\left(\text { IU. } .^{-1}\right)\end{array}$ & $\begin{array}{l}\text { ALP } \\
\left(\text { IU. } .^{-1}\right)\end{array}$ & $\begin{array}{l}\text { AST } \\
\left(\text { IU. } .^{-1}\right)\end{array}$ \\
\hline Control & $\begin{array}{l} \pm 2.88 \\
0.11 \mathrm{a}\end{array}$ & $\begin{array}{l} \pm 4.78 \\
0.24 \mathrm{~b}\end{array}$ & $\begin{array}{l}1.90 \pm \\
0.21 \mathrm{~b}\end{array}$ & $\begin{array}{c}1.63 \pm \\
0.23 \mathrm{a}\end{array}$ & $\begin{array}{c}204.08 \pm \\
2.66 \mathrm{a}\end{array}$ & $\begin{array}{l}1.20 \pm \\
0.03 \mathrm{a}\end{array}$ & $\begin{array}{c}36.42 \pm \\
5.13 \mathrm{~b}\end{array}$ & $\begin{array}{c}30.85 \pm \\
1.26 \mathrm{a}\end{array}$ \\
\hline Safmannan & $2.15 \pm$ & \pm 4.96 & $2.80 \pm$ & $0.775 \pm$ & $173.81 \pm$ & $1.23 \pm$ & $36.62 \pm$ & $29.30 \pm$ \\
\hline $\begin{array}{c}500 \mathrm{mg} \cdot \mathrm{kg} \\
\mathrm{diet}^{-1}\end{array}$ & $0.08 \mathrm{~b}$ & $0.11 \mathrm{~b}$ & $0.09 \mathrm{a}$ & $0.04 \mathrm{~b}$ & $9.12 \mathrm{~b}$ & $0.03 \mathrm{a}$ & $1.83 \mathrm{~b}$ & $0.90 \mathrm{a}$ \\
\hline Safmannan & $2.23 \pm$ & $5.47 \pm$ & $3.24 \pm$ & $0.719 \pm$ & $184.43 \pm$ & $1.19 \pm$ & $36.47 \pm$ & $30.34 \pm$ \\
\hline $\begin{array}{l}1000 \mathrm{mg} \cdot \mathrm{kg} \\
\text { diet }^{-}\end{array}$ & $0.13 \mathrm{~b}$ & $0.16 \mathrm{a}$ & $0.18 \mathrm{a}$ & $0.07 \mathrm{~b}$ & $6.21 \mathrm{ab}$ & $0.02 \mathrm{a}$ & $5.16 \mathrm{~b}$ & $0.84 \mathrm{a}$ \\
\hline Fluconazole & \pm 2.63 & \pm 4.84 & $2.12 \pm$ & $1.72 \pm$ & $201.70 \pm$ & $1.25 \pm$ & $54.30 \pm$ & $24.57 \pm$ \\
\hline $\begin{array}{c}\text { 150mg.100 } \\
\text { diet }^{-1}\end{array}$ & $0.12 \mathrm{a}$ & $0.69 \mathrm{~b}$ & $0.64 \mathrm{~b}$ & $0.29 \mathrm{a}$ & $3.98 \mathrm{a}$ & $0.06 \mathrm{a}$ & $4.62 \mathrm{a}$ & $1.96 \mathrm{~b}$ \\
\hline $\begin{array}{c}\text { Significant } \\
\text { level }\end{array}$ & ** & $* *$ & $* *$ & $* *$ & * & NS & * & $* *$ \\
\hline
\end{tabular}

Table (6) exhibited no significant differences among all the treatments in the packed cell volume $(\mathrm{PCV})$ and haemoglobin $(\mathrm{Hb})$ with $40.01,43.00,39.06$ and $41.75 \%$ for PCV and $13.33,14.32,13.02$ and 13.91, respectively for haemoglobin. Eosinophils and basophils did not recorded significant differences among the treatments with $1.23,1.26,1.31$ and $1.33 \%$ for Eosinophils and 1.23, 1.26, 1.19 and $1.22 \%$ for basophils. Neutrophil did not showed significant differences among the second, third and fourth treatments, and all were significantly decreased $(p<0.05)$ from the control with 22.57 compared with 20.24, 19.65 and 20.72, respectively. A granulocytes lymphocytes and monocytes did not revealed significant differences among the treatments with 73.85, $76.04,76.59$ and $75.24 \%$ and 1.12, 1.20, 1.26 and 1.49 , respectively (Table 6).

\section{Hepatosomatic index (HSI) and spleen somatic index (SSI)}

Table (7) indicated a significant increase ( $p$ $<0.05)$ in the hepatosomatic index for the last three treatments $(2.482,2.47$ and 2.60) compared with the control (2.032). On other hand, these three treatments were not significantly different among them. The values of the spleen somatic index did not show significant differences among them with 0.021 , $0.029,0.046$ and 0.033 , respectively. 
Table (6): Effect of dietary Safmannan or Fluconazole on packed cell volume (PCV) and haemoglobin $(\mathrm{Hb})$ and the differential white blood cell count of common carp (Mean $\pm \mathrm{SE}$ ).

\begin{tabular}{|c|c|c|c|c|c|c|c|}
\hline Treatment & PCV & $\mathrm{Hb}$ & Eosinophil & Basophil & Neutrophil & Lymphocyte & Monocyte \\
\hline Control & $\begin{array}{c}40.01 \pm \\
1.30 \mathrm{a}\end{array}$ & $\begin{array}{c}13.33 \pm \\
0.43 \mathrm{a}\end{array}$ & $\begin{array}{l}1.23 \pm \\
0.07 \mathrm{a} \\
\end{array}$ & $\begin{array}{l}1.23 \pm \\
0.02 \mathrm{a}\end{array}$ & $\begin{array}{c}22.57 \pm \\
0.55 \mathrm{a}\end{array}$ & $\begin{array}{c}73.85 \pm \\
0.50 \mathrm{a}\end{array}$ & $\begin{array}{l}1.12 \pm \\
0.07 \mathrm{a}\end{array}$ \\
\hline $\begin{array}{c}\text { Safmannan } \\
500 \mathrm{mg} \cdot \mathrm{kg} \mathrm{diet}^{-1}\end{array}$ & $\begin{array}{c}43.00 \pm \\
2.03 \mathrm{a}\end{array}$ & $\begin{array}{c}14.32 \pm \\
0.67 \mathrm{a}\end{array}$ & $\begin{array}{l}1.26 \pm \\
0.09 \mathrm{a}\end{array}$ & $\begin{array}{l}1.26 \pm \\
0.04 \mathrm{a}\end{array}$ & $\begin{array}{c}20.24 \pm \\
0.28 \mathrm{~b}\end{array}$ & $\begin{array}{c}76.04 \pm \\
0.88 \mathrm{a}\end{array}$ & $\begin{array}{l}1.20 \pm \\
0.03 \mathrm{a}\end{array}$ \\
\hline $\begin{array}{c}\text { Safmannan } \\
1000 \text { mg.kg diet }{ }^{-1}\end{array}$ & $\begin{array}{c}39.06 \pm \\
0.61 \mathrm{a}\end{array}$ & $\begin{array}{c}13.02 \pm \\
0.20 \mathrm{a}\end{array}$ & $\begin{array}{l}1.31 \pm \\
0.02 \mathrm{a}\end{array}$ & $\begin{array}{l}1.19 \pm \\
0.04 \mathrm{a}\end{array}$ & $\begin{array}{l}19.65 \pm \\
0.43 \mathrm{~b}\end{array}$ & $\begin{array}{c}76.59 \pm \\
0.85 \mathrm{a}\end{array}$ & $\begin{array}{l}1.26 \pm \\
0.04 \mathrm{a}\end{array}$ \\
\hline $\begin{array}{c}\text { Fluconazole } \\
\text { 150mg.100 } \mathrm{g} \mathrm{diet}^{-1}\end{array}$ & $\begin{array}{l}41.75 \pm \\
1.03 \mathrm{a}\end{array}$ & $\begin{array}{c}13.91 \pm \\
0.34 \mathrm{a}\end{array}$ & $\begin{array}{l}1.33 \pm \\
0.02 \mathrm{a}\end{array}$ & $\begin{array}{l}1.22 \pm \\
0.02 \mathrm{a}\end{array}$ & $\begin{array}{l}20.72 \pm \\
0.71 \mathrm{~b}\end{array}$ & $\begin{array}{c}75.24 \pm \\
0.35 \mathrm{a}\end{array}$ & $\begin{array}{l}1.49 \pm \\
0.06 \mathrm{a}\end{array}$ \\
\hline Significant level & NS & NS & NS & NS & $*$ & NS & NS \\
\hline
\end{tabular}

Means with different letters within the same column differ significantly among them * $(\mathrm{P}<0.05) * *(\mathrm{P}<0.01)$.

Table (7): Effect of dietary Safmannan or Fluconazole on the on the hepatosomatic Index (HSI) and spleen somatic index (SSI) of the common carp (Mean \pm SE).

\begin{tabular}{|c|c|c|}
\hline Treatment & HSI & SSI \\
\hline Control & $\pm 2.0320 .12 \mathrm{~b}$ & $0.021 \pm 0.003 \mathrm{a}$ \\
\hline Safmannan 500 mg.kg diet ${ }^{-1}$ & $2.482 \pm 0.12 \mathrm{a}$ & $0.029 \pm 0.01 \mathrm{a}$ \\
\hline Safmannan 1000 mg.kg diet ${ }^{-1}$ & $2.47 \pm 0.13 \mathrm{a}$ & $0.046 \pm 0.01 \mathrm{a}$ \\
\hline Fluconazole $150 \mathrm{mg} .100 \mathrm{~g} \mathrm{diet}^{-1}$ & $2.60 \pm 0.13 \mathrm{a}$ & $0.033 \pm 0.012 \mathrm{a}$ \\
\hline Significant level & $*$ & N.S \\
\hline
\end{tabular}

Means with different letters within the same column differ significantly among them * $(\mathrm{P}<0.05) * *(\mathrm{P}<0.01)$.

\section{Growth parameters}

In aquaculture, the conditions which result from stress, water quality and nutrition are interacted factors, complementing each other and any damage can affect the physiological and immunological status of the affected animal and making it susceptible to the disease (Staykov et al., 2007). The positive results obtained in the growth traits (daily weight gain, feed conversion ratio and daily growth rate) when using the prebiotic (Safmannan) compared with the control group can be attributed to stimulating the targeted microorganisms for growth and reproduction, leading to an increase in the conversion of complex contents to simple materials. This, in turn, ends in the production of some digestive enzymes for starch, proteins and fatty substances (El-Haroun et al., 2006; Azevedo et al., 2015). Thus, it leads to activate the role of the trypsin and amylase enzymes in the intestine, the increase in the activity of digestive enzymes and the developing of the microvillus structure on the inner surface of intestinal cells which in turn increases the surface area of nutrient absorption, which in turn bring about to increasing efficiency of 
food utilization compared with the control group (Zhou et al., 2010; Anguiano et al., 2013).

The results of the study coincided with those of Staykov et al. (2005), which revealed significant surpassing for the growth rates of rainbow trout fed on a diet supported with prebiotic MOS compared with unsupported diet (control). This may be attributed to stimulating the growth, reproduction and colonization of beneficial microorganisms at the expense of other non-beneficial pathological microorganisms, and the consequent improving digestion of consumed feed and absorbing it in intestine. Similar results were obtained by Mazurkiewicz et al. (2008) when feeding common carp on prebiotic (Fermacto) at concentrations of 1, 2 and $3 \mathrm{~g} . \mathrm{kg}^{-1}$ diet, where it showed significant superiority compared with the control diet in both the specific growth rates and the feed conversion ratio which attributed to stimulating the voluntary growth for endemic organisms in gut. Also, the present results are coincided with Kühlwein et al. (2014) when adding 5 and $10{\mathrm{~g} . \mathrm{kg}^{-1}}^{-}$diet from the prebiotic (Beta-glucan) in the diet of the mirror carp for eight weeks and obtained high values for weight indicators. The results of the present study also are comparable with the study of Eleraky et al. (2014) when adding 1.5 and 2.5 g. $\mathrm{kg}^{-1}$ diet from the prebiotic containing MOS and Beta-glucans (1:3 and 1:6) in the feeding of common carp fries, when they showed a significant superiority compared with the control diet in terms of the final weight of the body and the average of specific growth and weight gain. They are also agreed with the results of Amani Denji et al. (2015), when adding 1, 2.5 and $4.0 \mathrm{~g} . \mathrm{kg}^{-1}$ diet from the prebiotic (mannan oligosaccharide) in the feeding of rainbow trout (Oncorhynchus mykiss), where it showed a significant superiority compared with the control diet in terms of the final weight of the body and the average of specific growth and weight gain. However, the results did not agree with the results mentioned by Genc et al. (2007), which did not show significant differences between the Oreochromis niloticus $\times O$. aureus fed on different levels of MOS compared with the control diet in both growth performance and final weight and growth rate, in addition to the feed conversion ratio and protein efficiency ratio for the duration of the experiment. The results of the current study did not agree with Dobšíková et al. (2013) when feeding common carp on beta-glucans, where a reduction in the weight gain was observed.

Antibiotics have been used to feed fish as growth promoters and immune stimuli by many researchers (Ahmad et al., 2008; Rodgers \& Furones, 2009), so they has been used as a treatment compared with the prebiotic, which many researches has illustrated their importance in increasing the beneficial bacteria and reduce the number of pathogenic ones by preventing the adhesion of pathogenic bacteria mediated by the villi in the lining of the digestive tract, which prevents their association with epithelial cells, which means that these bacteria are out of the body, thus cause no injury (Wysong, 2003). Therefore, a free from dietary additives diet, was used as a negative control treatment and antibiotics as a positive control treatment to make comparison on the effect of these additives (antibiotic and safmannan) on the growth and traits of blood and biochemical parameters and some fish organs. The results of the present study are in agreement with those of El-Houseiny et al. (2015) when compared by using the prebiotic (Cinnamon) and bio-antibiotic (oxytetracycline) in the diet of Nile tilapia which exhibited significant 
superiority in prebiotic compared with bioantibiotic in terms of final weight, the weight gain and daily growth rate, along with resistance of fishes fed on the prebiotic for pathogenic bacteria (Clostridium perfringens). These results did not coincide with the results of Reda et al. (2013) when adding $100 \mathrm{mg} \cdot \mathrm{kg}^{-1}$ diet from prebiotic (oxytetracycline) and $5 \mathrm{mg} \cdot \mathrm{kg}^{-1}$ diet from Florfenicol for cultured Nile tilapia where the addition led to an increase in final weight and a significant increase in the weight gain and feed conversion ratio compared with basal diet.

\section{Haemato-immunological parameters}

Blood is considered as one of the important tissue for determining the health of fishes that are given dietary supplement where they determine the suitability of the added feed. However, biochemical criteria are considered as one of the methods for determining fish health and their breeding conditions in terms of stress and disease (Peres et al., 2013; Gharaei et al., 2016).

The treatments with dietary safmannan of the current study revealed significantly higher values in immunological parameters compared with control, and the increase of protein in the serum was associated with high immune response in the body (Wiegertjes et al., 1996; Ta'ati et al., 2011). Similar results could see in the study of Ebrahimi et al. (2011) when using the prebiotic (immunogen) at concentrations of $0.5,1,1.5$ and $2.5 \mathrm{~g} . \mathrm{kg}^{-1}$ diet in the nutrition of young common carp in value of the serum protein, but did not agree with the level of globulin and albumin and the albumin/globulin ratio and hence may be resulted from the type of prebiotic and the ecological criteria between the studies. It was worth to mention that the low cholesterol in safmannan treatments (second and third treatments) is advantage result in the current study and this significant difference compared with the control is due to the prebiotic which led to increase growing the beneficial bacteria in the intestine, which increase secretion of organic acids, thus inhibits the activity of enzymes that prevent the building of fatty acids (Chen et al., 2014).

When using bio-antibiotic (fluconazole), it did not show significant differences in the level of albumin, globulin, total protein and cholesterol compared with the control. These results agreed with Saha et al. (2017) when giving dietary fluconazole for Labeo rohita at concentrations of 100, 200 and $300 \mathrm{mg} .100 \mathrm{~g}^{-}$ ${ }^{1}$ diet, where it did not record significant differences in the level of total protein in the concentration of 100 and 300 compared with the control, while it recorded a decrease in the level of total protein at the concentration of $200 \mathrm{mg} .100 \mathrm{~g}^{-1}$ diet. The same study recorded no significant differences in albumin at the $30^{\text {th }}$ and $45^{\text {th }}$ days and no significant differences in globulin during 15 and 30 days from experiment and hence agreed with the present results.

\section{Liver enzymes}

The activity of enzymes varies depending on the quality of the fishes (Shalaby, 2005). The activity of ALP, ALT and AST enzymes in the serum can be used to monitor of fish health due to the increased permeability of damaged hepatocytes which cause a liberation of these enzymes into the blood (Suárez et al., 2015). The results of the ALT and AST in the second and third treatments (500 and 1000 safmannan, respectively) revealed no significant differences compared with the control, which means that the concentrations of enzymes are within the normal ranges of the prebiotic treatments. 
Akrami et al. (2013) found similar results when they recorded no significant differences in the treatments of MOS with two levels (2 and 4 g. $\mathrm{kg}^{-1}$ diet) when fed great sturgeon (Huso huso). In addition, similar upshots were demonstrated by Amani Denji et al. (2015) when adding 1, 2.5 and $4.0 \mathrm{~g} . \mathrm{kg}^{-1}$ diet of prebiotic MOS and by Adel et al. (2017) when feeding juvenile $H$. huso on the prebiotic GroBiotic with different concentrations. In the case of bio-antibiotic (fluconazole), there were significant differences in the enzymes of AST and ALP, while there were no differences in ALT compared with the control. This rise in the level of liver enzymes was due to the stress and toxicity of which the fishes were exposed due to the continuous using of antibiotics (Ovie et al., 2010). Related results were demonstrated by Reda et al. (2013) when adding bio-antibiotic oxytetracycline and Florfenicol by 5 and $100 \mathrm{mg} \cdot \mathrm{kg}^{-1}$ feed, respectively to the Nile tilapia where AST values showed significant differences compared with the control.

\section{Hemoglobin (Hb) and packed cell volume (PCV)}

Knowing blood criteria is considered as one of the main indicators in diagnosing the health status of fishes especially when some additives are used in feeding (Abu-Elala et al., 2013). Plosker \& Figgitt (2003) indicated that the PCV is considered as an indicator of environmental influences and sometimes as a pathological case. The current results presented no significant differences in hemoglobin $(\mathrm{Hb})$ and PCV. Welker et al. (2007) noted same results in both parameters when fed Channel catfish (Ictalurus punctatus) on the MOS. Also, Akrami et al. (2013) when feeding great sturgeon (Huso huso) on two levels of MOS (2 and 4 g. $\mathrm{kg}^{-1}$ feed) and Amani Denji et al. (2015) when adding MOS with 1, 2.5, 4.0 g. $\mathrm{kg}^{-1}$ feed on rainbow trout (Oncorhynchus mykiss) and with Gelibolu et al. (2018) when adding different concentrations of the prebiotic MOS by $1,2,3$ and 4 g. $\mathrm{kg}^{-1}$ diet to Sea bream (Sparus aurata), while Akrami et al. (2012) used prebiotic MOS (1, 2 and $3 \mathrm{~kg}^{-1}$ diet) in feeding common carp and found significant differences in PCV with treatment of $1 \mathrm{~kg}^{-1}$ diet.

Regarding fluconazole, there were no significant differences compared with the control in the PCV and hemoglobin ( $\mathrm{Hb})$, which agreed with Saha et al. (2017) in the PCV when used dietary fluconazole (100, 200 and $300 \mathrm{mg} \cdot \mathrm{g}^{-1} \mathrm{diet}$ ) to Labeo rohita in the $15^{\text {th }}$ and $45^{\text {th }}$ days of the experiment. For $\mathrm{Hb}$, in the same experiment, it was applied with the results of the present investigation on the $45^{\text {th }}$ day, where no significant differences were recorded, while there were significant differences in the $15^{\text {th }}$ and $30^{\text {th }}$ days of the experiment.

\section{HSI and SSI}

The hepato-somatic index (HSI) revealed significant differences compared with the control, while the spleen somatic index (SSI) did not display significant differences among the treatments. There were differences among the treatments compared with the control, excelled by the treatment (T2), where these results supported the theory that the prebiotic improves the health of a particular animal and provides a beneficial physiological effect (Hutkins et al., 2016). Ashourpour et al. (2012) noted the same findings when fed Acipenser nudiventris on different concentrations of the prebiotic $(0.5,1$ and 1.5 g. $\mathrm{kg}^{-1} \mathrm{diet}$ ), where significant differences were found in HSI of all treatments compared with the control. Ahmed (2014) investigated the 
comparative effect of a prebiotic Fructooligosaccharide (FOS) and a probiotic (Saccharomyces cerevisiae) and their combination in different levels as a symbiotic on young common carp. The study did not recorded significant differences in hepatosomatic index in all eight treatments except in probiotic with dietary yeast of $2.5 \mathrm{~g} \cdot \mathrm{kg}^{-1}$ diet.

\section{Differential WBC count}

White blood cells are the most important immune defences in vertebrates (Tierney \& Farrell, 2004) where number of white blood cells may increase in response to disease, season, environmental conditions and physiological status of fishes. Number of WBC in fishes cannot be determined because they are few compared with red blood cells. Therefore, their use as an index for pathological infections is limited (Hoole et al., 2001).

The present results did not displayed significant differences in the differential WBC count but demonstrated significant superiority in the number of neutrophils in fishes fed on the control diet, which may be due to the stress of fishes fed on the diets free from the health-promoting prebiotic. In lymphocyte cells, although there was no significant differences, but they exhibited statistical excelling in prebiotic treatments compared with the control. Similar findings were illustrated by Amani Denji et al. (2015) when rainbow trouts were fed with 1, 2.5 and $4.0 \mathrm{~g}$. $\mathrm{kg}^{-1}$ diet of the prebiotic MOS, where it did not showed significant differences compared with the control diet in terms of lymphocytes and eosinophils. In contrast, Akrami et al. (2012) revealed that feeding of common carp with 1,2 and 3 g. $\mathrm{kg}^{-1}$ diet prebiotic MOS have a significant superiority at a concentration of $1 \mathrm{~g} . \mathrm{kg}^{-1}$ diet compared with the control in terms of lymphocytes. The reason for this rise is due to the effect of prebiotic in immunostimulation of fishes. Ahmed (2014) recorded significant increasing in granulocytes count in FOS $5 \mathrm{~g} \cdot \mathrm{kg}^{-1}$ diet and significant increasing in monocytes count in symbiotic treatment FOS $2.5 \mathrm{~g} \cdot \mathrm{kg}^{-1}$ diet with yeast $\left(2.5 \mathrm{~g} \cdot \mathrm{kg}^{-1} \mathrm{diet}\right)$.

\section{Conclusion}

Adding Safmannan to the diet exhibited positive results in growth parameters, healthy aspects and the liver enzymes. The present adding of Safmannan in the diet is still in the normal concentrations. The biochemical criteria exhibited better in safmannan treatment compared with the antibiotic and the control treatments. It is recommended to use dietary safmannan in heavy aquaculture system especially in cage culture to immuno stimulate fishes toward various pathogens.

\section{Acknowledgements}

The authors would like to thank staff of Department of Fisheries and Marine Resources, College of Agriculture, University of Basrah for offering space and support the study, to Dr. Ahmed M.S. Al-Jana'ee from Basrah Directorate of Agriculture, Ministry of Agriculture for his assistance in haematological analyses.

Conflict of interest: The authors declare that they have no conflict of interest.

Ethical approval: all applicable national and international guidelines for the care and use of animals were followed.

\section{References}

Abu-Elala, N.; Marzouk, M. \& Moustafa, M. (2013). Use of different Saccharomyces cerevisiae biotic forms as immunemodulator and growth promoter for Oreochromis niloticus challenged with 
some fish pathogens. Int. J. Vet. Sci. Med., 1: 21-29.

Adel, M.; Safari, R.; Yeganeh, S.; Binaii, M.; Ghiasi, M. \& Ahmadvand, S. (2017). Effect of dietary GroBiotic $®-A$ supplementation as a prebiotic on the intestinal microflora, growth performance, haemato-serological parameters, survival rate and body composition in juvenile beluga (Huso huso Linnaeus, 1754). Aquac. Nutr., 23(3): 492-499. DOI: 10.1111/anu.12417.

Ahmad, H.M.; Eid, A.M.S.; Al-Danasoury, A.M.E.; Khouraiba, E.R.M.A. \& El-Aidy, E.S.B. (2008). Studies on using oxytetracycline as a growth promoter in fingerlings Nile tilapia (Oreochromis niloticus) diets. Suez Canal Vet. Med. J., 13(2): 497- 511.

Ahmed, V.M. (2014). Comparative effects of probiotic (Saccharomyces cereviciae), prebiotic (Fructooligosaccharide FOS) and their combination on growth performance and some blood indices in young common carp (Cyprinus carpio L.). M. Sc. Thesis. Fac. Agric. Sci., Univ. Sulaimani: 97pp.

Akrami, R.; Razeghi-Mansour, M.; Chitsaz, H.; Ziace, R. \& Ahmadi, Z. (2012). Effect of dietary mannan oligosaccharide on growth performance, survival, body composition and some hematological parameters of carp juvenile (Cyprinus carpio). J. Anim. Sci. Adv., 2(11): 879885.

Akrami, R.; Razeghi Mansour, M.; Ghobadi, Sh.; Ahmadifar, E.; Shaker Khoshroudi, M. \& Moghimi Haji, M.S. (2013). Effect of prebiotic mannan oligosaccharide on hematological and blood serum biochemical parameters of cultured juvenile great sturgeon (Huso huso
Linnaeus, 1754). J. Appl. Ichthyol., 29(6): 1214-1218.

Al-Ashaab, M.H. (2011). Addition of different type and levels of omega- 3 and omega-6 enriched diets on the growth performance of common carp (Cyprinus carpio L.) fingerlings. Ph. D. Thesis, Coll. Agric., Univ. Baghdad: 177pp. (In Arabic).

Allameh, S.K.; Yusoff, F.M.; Ring $\varnothing$, E.; Daud, H.M.; Saad, C.R. \& Ideris, A. (2016). Effects of dietary mono-and multiprobiotic strains on growth performance, gut bacteria and body composition of Javanese carp (Puntius gonionotus Bleeker, 1850). Aquac. Nutr., 22(2):

367-373.

15https://doi.org/10.1111/anu.12265.

Amani Denji, K.; Razeghi Mansour, M.; Akrami, R.; Ghobadi, Sh.; Jafarpour, S.A. \& Mirbeygi, S.K. (2015). Effect of dietary prebiotic mannan oligosaccharide (MOS) on growth performance, intestinal microflora, body composition, haematological and blood serum biochemical parameters of rainbow trout (Oncorhynchus mykiss) juveniles. J. Fish. Aquat. Sci., 10(4): 255-265.

Anguiano, M.; Pohlenz, C.A.B.; Buentello, A. \& Gatlin, D.M. (2013). The effects of prebiotics on the digestive enzymes and gut histomorphology of red drum (Sciaenops ocellatus) and hybrid striped bass (Moronechrysops $\times$ M. saxatilis). $\mathrm{Br}$. J. Nutr., 109(4): 623-629.

Ashourpour, A.; Zamini, A.A.; Yazdani, M.A. \& Masouleh, A.S. (2012). The efficacy of dietary prebiotic Saccharomyces cerevisiae cell wall on growth indices, survival rate and carcass proximate composition in fingerlings Acipenser nudiventris. Global 
Aquaculture securing our future. 1-5 September, 2012. Prague, Czech Rep.: 1p.

Azevedo, R.V.; Fosse Filho, J.C.; Cardoso, L.D.; Mattos, D.C.M.; Júnior, M.V.V. \& de Andrade, D.R. (2015). Economic evaluation of prebiotics, probiotics and symbiotics in juvenile Nile tilapia. Rev. Ciênc. Agron., 46(1): 72-79. DOI.org/10.1590/S1806.66902015000100 009.

Baldry, I. (2000). Effect of common carp (Cyprinus carpio L.) on aquatic restorations. Restor. Reclam. Rev., 6(6): 18.

Bandyopadhyay, P.; Mishra, S.; Sarkar, B.; Swain, S.K.; Pal, A.; Tripathy, P.P. \& Ojha, S.K. (2015) .Dietary Saccharomyces cerevisiae boosts growth and immunity of IMC Labeo rohita (Ham.) juveniles. Indian J. Microbial., 55(1): 81-87.

Boyd, C.E. \& Tucker, C.S. (1998). Pond Aquaculture Water Quality management. Kluwer Academic Publishers, Boston: 700pp.

Brogden, G.; Krimmling, T.; Adamek, M.; Naim, H.Y.; Steinhagen, D. \& von Köckritz-Blickwede, M. (2014) .The effect of $\beta$-glucan on formation and functionality of neutrophil extracellular traps in carp (Cyprinus carpio L.). Dev. Comp. Immunol., 44(2): 280-285.

Campbell, T.W. (1995). Avian Hematology and Cytology, $2^{\text {nd }}$ ed., Iowa State Univ. Press, Ames, Iowa: 104pp.

Carrias, A.; Ran, C.; Terhune J.S. \& Liles, M.R. (2012). Bacteria and bacteriophages as biological agents for disease control in aquaculture: 353-393. In: Austin, B. (Ed.). Infectious Disease in Aquaculture: Prevention and Control. Woodhead
Publishing Series in Food Science, Technology and Nutrition: 560pp.

Chen, Y.; Zhu, X.; Yang, Y.; Han, D.; Jin, J. $\&$ Xie, S. (2014) .Effect of dietary chitosan on growth performance, haematology, immune response, intestine morphology, intestine microbiota and disease resistance in gibel carp (Carassius auratus gibelio). Aquac. Nut., 20(5): 532-546.

Dobšíková, R.; Blahová, J.; Mikulíková, I.; Modrá, H.; Prášková, E.; Svobodová, Z.; Škorič, M.; Jarkovský, J. \& Siwicki, A.-K. (2013). The effect of oyster mushroom $\beta$ 1.3/1.6-D-glucan and oxytetracycline antibiotic on biometrical, haematological, biochemical, and immunological indices, and histopathological changes in common carp (Cyprinus carpio L.). Fish Shellfish Immunol., 35(6): 1813-1823.

Duncan, D.B. (1955). Multiple range and multiple F-test. Biometrics, 11(1): 4-42.

Ebrahimi, G.; Ouraji, H.; Khalesi, M.K.; Sudagar, M.; Barari, A.; Zarei Dangesarak, M. \& Jani Khalili, K.H. (2011).Effects of a prebiotic, Immunogen ${ }^{\circledR}, \quad$ on feed utilization, body composition, immunity and resistance to Aeromonas hydrophila infection in the common carp Cyprinus carpio (Linnaeus) fingerlings. J. Anim. Physiol. Anim. Nutr. (Berl.), 96(4): 591599. DOI: $\quad$ 10.1111/j.14390396.2011.01182.x.

Eleraky, W.; Yahya, M.; Reda, R.M. \& Eletreby, S. (2014). Evaluation of prebiotic and probiotic dietary supplementation on growth performance and some blood parameters of Cyprinus carpio frys. Egypt. J. Aquat. Biol. Fish., 18(2): 29-38. DOI: 10.21608/ejabf.2014.2203.

El-Haroun, E.R.; Goda, A.M.A.-S. \& Kabir Chowdhury, M.K. (2006). Effect of dietary 
probiotic Biogen ${ }^{\circledR}$ supplementation as a growth promoter on growth performance and feed utilization of Nile tilapia Oreochromis niloticus (L.). Aquac. Res., 37(14): 1473-1480.

El-Houseiny, W.; Khalil, A.A. \& Mowafy, R.E. (2015). Immunological and pathological studies on (Oreochromis niloticus) fed on cinnamon and ox tetracycline in diet and challenged with Clostridium perfringens. Abbassa Int. J. Aqua., 8(1): 1-19.

Gelibolu, S.; Yanar, Y.; Ayce Genc, M. \& Genc, E. (2018). Effects of Mannanoligosaccharide (Mos) supplementation on growth and some blood parameters of gilthead Seabream (Sparus aurata). Turk. J. Fish. Aquat. Sci., 18(6): 817-823.

Genc, M.A.; Yilmaz, E.; Genc, E. \& Aktas, M. (2007). Effects of dietary mannan oligosaccharides (MOS) on growth, body composition, and intestine and liver histology of the hybrid tilapia (Oreochromis niloticus $\times$ O. aureus). Isr. J. Aquac., 59: 10-16.

Gharaei, A.; Rayeni; M.F.; Ghaffari, M.; Akrami, R. \& Ahmadifar, E. (2016). Influence of dietary prebiotic mixture $(\alpha-$ mune) on growth performance, haematology and innate immunity of beluga sturgeon (Husohuso) juvenile. Int. J. Aquat. Biol., 4(4): 277-284.

Hepher, B. (1988). Nutrition of Pond Fish. Cambridge Univ. Press: 385pp. https://doi.org/10.1017/CBO97805117354 55 .

Herwig, N. (1979). Handbook of Drugs and Chemicals used in the Treatment of Fish Disease. Charles C. Thomas Publ., Springfield, Illinois: $x v+272 p p$.
Hoole, D.; Bucke, D.; Burgess, P. \& Wellby, I. (Eds.) (2001). Diseases of Carp and Other Cyprinid Fishes. Iowa State Univ. Press, Ames, Iowa: 280pp.

Hutkins, R.W.; Krumbeck, J.A.; Bindels, L.B.; Cani, P.D.; Fahey, Jr.G.; Goh, Y.J.; Hamaker, B.; Martens, E.C.; Mills, D.A.; Rastal, R.A.; Vaughan, E. \& Sanders, M.E. (2016) .Prebiotics: Why definitions matter. Curr. Opin. Biotechnol., 37: 1-7.

Kühlwein, H.; Merrifield, D.L.; Rawling, M.D.; Foey, A.D. \& Davies, S.J. (2014) . Effects of dietary $\beta$-(1,3)(1,6)-D-glucan supplementation on growth performance, intestinal morphology and haematoimmunological profile of mirror carp (Cyprinus carpio L.). J. Anim. Physiol. Anim. Nutr., 98(2): 279-289.

Lovell, T. (1989). Nutrition and Feeding of Fish. Van Nostra and Reinhold. New York: 260pp.

Mangat, H.K. \& Hundal, S.S. (2014). Salinity tolerance of laboratory reared fingerlings of common carp, Cyprinuscarpio (Linn.) during different seasons. Int. J. Adv.Res.,2(11): 491-496.

Mazurkiewicz, J.; Przybył, A. \& Golski, J. (2008). Usability of Fermacto prebiotic in feeds for common carp (Cyprinus carpio L.) fry. Nauka Przyr. Technol., 2(3): 15: 9pp.

Mumford, S.; Heidel, J.; Smith, C.; Morrison, J.; MacConnell, B. \& Blazer, V. (2007). Fish Histology and Histopathology. U.S. Fish and Wildlife Services (USFWS). National Conservation Training Center (NCTC): 356pp. https://training.fws.gov/resources/courseresources /fish-histology/FishHistology_Manual_v4.pdf. 
Imran et al / Basrah J. Agric. Sci., 32 (2):186-202, 2019

Ovie, K.-S.; Bemigho, I.R. \& Gbemi, O.M. (2010). Variations in alanine aminotransferase and aspartate aminotransferase activities in African catfish: Clarias gariepinus (Burchell, 1822) at different sublethal concentrations of potassium permanganate. Sci. Res. Essays, 5(12): 1501-1505.

Palić, D.; Beck, L.S.; Palić, J. \& Andreasen, C.B. (2011). Use of rapid cytochemical staining to characterize fish blood granulocytes in species of special concern and determine potential for function testing. Fish Shellfish Immunol., 30(2): 646-652.

Peres, H.; Santos, S. \& Oliva-Teles, A. (2013). Selected plasma biochemistry parameters in gilthead seabream (Sparus aurata) juveniles. J. Appl. Ichthyol., 29(3): 630-636.

Plosker, G.L. \& Figgitt, D. (2003). Rituximab: A review of its use in nonHodgkin's lymphoma and chronic lymphocytic leukaemia. Drugs, 63(8): 803843.

Reda, R.M.; Ibrahim, R.E.; Ahmed, E.G. \& El-Bouhy, Z.M. (2013). Effect of oxytetracycline and florfenicol as growth promoters on the health status of cultured Oreochromis niloticus. Egypt. J. Aquat. Res., 39: 241-248.

Richards, R.H. \& Pickering, A.D. (1979). Changes in serum parameters of Saprolegnia-infected brown trout, Salmo trutta L. J. Fish Dis., 2(3): 197-206.

Rodgers, C.J. \& Furones, M.D. (2009). Antimicrobial agents in aquaculture: Practice, needs and issues: 41-59. In: Rogers, C. \& Basurco, B. (Eds.). The Use of Veterinary Drugs and Vaccines in Mediterranean Aquaculture. Zaragoza.
CIHEAM: 223pp. http://om.cih eam.org/article.ph p?ID PDF=801061.

Saha, H.; Pal, A.K.; Sahu, N.P.; Saha, R.K. \& Goswami, P. (2017). Effects of fluconazole based medicated feed on haematoimmunological responses and resistance of Labeo rohita against Saprolegnia parasitica. Fish Shellfish Immunol., 71:346-352.

SAS (2012). Statistical Analysis System, User's Guide. Statistical. Version

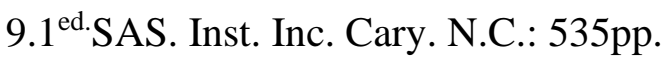

Schreck, C.B. \& Moyle, P.B. (1990) .Methods for Fish Biology. Am. Fish. Soc., Bethesda, Maryland: xix + 684pp.

Shalaby, A.M.E. (2005). The opposing effect of ascorbic acid (Vitamin C) on ochratoxin toxicity in Nile tilapia Oreochromis niloticus. Proc. $6^{\text {th }}$ Int. Symp. Tilapia Aquac., Philippines: 209-221.

Staykov, Y.; Denev, S. \& Spring, P. (2005). Influence of dietary mannan oligosaccharide (Bio-Mos) on growth rate and immune function of common carp (Cyprinus carpio L.). In: Howell, B. \& Flos, R. (Eds.). Lessons from the past to optimise the future. Europ. Aquac. Soc., Spec. Publ. No. 35: 431-432.

Staykov, Y.; Spring, P.; Denev, E.S. \& Sweetman, E.J. (2007). Effect of a mannan oligosaccharide on the growth performance and immune status of rainbow trout (Oncorhynchus mykiss). Aquac. Int., 15(2): 153-161. DOI: 10.1007/s10499-007-9096$\mathrm{z}$.

Suárez, M.D.; Trenzado, C.E.; GarcíaGallego, M.; Furné, M.; García-Mesa, S.; Domezain, A.; Alba, I. \& Sanz, A. (2015). Interaction of dietary energy levels and culture density on growth performance and metabolic and oxidative status of rainbow 
trout (Oncorhynchus mykiss). Aquac. Eng., 67: 59-66.

Ta'ati, R.; Soltani, M.; Bahmani, M. \&Zamini, A.A. (2011). Growth performance, carcass composition and immunophysiological indices in juvenile great sturgeon (Husohuso) fed on commercial prebiotic, immunostar. Iran. J. Fish. Sci., 10(2): 324335.

Tierney, K.B. \& Farrell, A.P. (2004). The relationships between fish health, metabolic rate, swimming performance and recovery in return-run sockeye salmon, Oncorhynchus nerka (Walbaum). J. Fish Dis., 27(11): 663-671. https://doi.org/10.1111/j.1365-2761.2004. 00590.x.

Tuan, K.N. (2013). Efficiency analysis and experimental study of cooperative behavior of shrimp farmers facing wastewater pollution in the Mekong river delta. Ph. D. Diss., Univ. Sydney Business School, School of Economics: 128pp.

Wang, L.; Lyons, J.; Kanehl, P. \& Gatti, R. (1997). Influences of watershed land use on habitat quality and biotic integrity in Wisconsin streams. Fisheries, 22(6): 6-12.

Welker, T.L.; Lim, C.; Yildirim-Aksoy, M.; Shelby, R. \& Klesius, P.H. (2007). Immune response and resistance to stress and Edwardsiella ictaluri challenge in channel catfish, Ictalurus punctatus, fed diets containing commercial whole-cell yeast or yeast subcomponents. J. World Aquac. Soc., 38(1): 24-35.

Wiegertjes, G.F.; Stet, R.J.M.; Parmentier, H.K. \& van Muiswinkel, W.B. (1996). Immunogenetics of disease resistance in fish: A comparable approach. Dev. Comp. Immunol., 20(6): 365-381.

Wisplinghoff, H.; Ebbers, J.; Geurtz, L.; Stefanik, D.; Major, Y.; Edmond, M.B.; Wenzel, R.P. \& Seifert, H. (2014). Nosocomial blood- stream infections due to Candida spp. in the USA :Species distribution, clinical features and antifungal susceptibilities. Int. J. Antimicrob. Agents, 43(1): 78-81.

Wolf, K. \& Darlington, R.W. (1971). Channel catfish virus: A new herpes virus of ictalurid fish. J. Virol., 8(4): 525- 533.

Wysong, D.L. (2003). Rationale for probiotic supplementation.http://www.wysong.net/P DFs /probiotic.pdf.

Yang, J.-L. \& Chen, H.-C. (2003). Serum metabolic enzyme activities and hepatocyte ultrastructure of common carp after gallium exposure. Zool. Stud., 42(3): 455-461.

Zhou, Q.-C.; Buentello, J.A. \& Gatlin III, D.M. (2010). Effects of dietary prebiotics on growth performance, immune response and intestinal morphology of red drum (Sciaenops ocellatus). Aquaculture, 309(14): 253-257. 